\title{
Pengaruh Latihan Aerobik Dan Anaerobik Terhadap Profil Lipid Pada Tikus Rattus Norvegicus Wistar
}

\author{
Budijanto \\ Program Studi Pendidikan Jasmani Kesehatan Dan Rekreasi IKIP Budi Utomo \\ Jalan Simpang Arjuno 14 B Malang \\ E-mail: budijanto.mkes@gmail.com
}

\begin{abstract}
Doing exercises regularly is useful to help improve strength, firmmess, and endurance and also to avoid early aging process The best exercises to make body healthy are swimming, quick hiking, jogging, and cycling. The goal of the research was to verify the difference of influence toward aerobic and anaerobic exercises towards the change of cholesterol, cholesterol HDL and LDL as well as ratio of cholesterol HDL and LDL. The research was experimental using post test and control group. The sample was classified into three groups, each of which consisting 10 mice and then randomly aerobic and anaerobic exercises and control group were done. The aerobic exercise by swimming used $3 \%$ burden of body weight for 13 minutes and the anaerobic exercise $9 \%$ for One minute by taking rest for 3 minutes intermittently as many as 4 sets, while control group did it without exercise. Based on the data analysis, it was found that aerobic exercises was effective to reduce cholesterol, improve cholesterol of HDL and LDL, and ratio of cholesterol of HDL and LDL. In addition the aerobic exercise was better than anaerobic exercise.
\end{abstract}

Keywords: exercise, improving, influence, cholesterol, HDL, LDL

Pembangunan Nasional yang dilaksanakan di Indonesia dalam semua aspek kehidupan akan meningkatkan taraf hidup dan kualitas hidup masyarakat baik yang tinggal di wilayah daerah perkotaan maupun pedesaan. Dampak sampingnya adalah meningkatnya modern, antara lain diet tinggi kalori, tinggi lemak dan kolesterol, merokok, minum alkohol dan lainlain. Penyakit yang dimaksud di antaranya adalah penyakit jantung dan pembuluh darah atau kardiovaskuler. Dilaporkan bahwa pada tahun 1993 penyakit ini menduduki urutan ke satu. Dalam melakukan suatu pencegahan diperlukan pengetahuan dasar tentang faktorfaktor yang berisiko misalnya diet, obatobatan, olahraga dan pembedahan atau operasi. Pencegahan yang dilakukan dengan berolahraga secara teratur akan memantu meningkatkan kekuatan, ketegaran dan daya tahan. Melindungi tubuh terhadap penyakit jantung, pembuluh darah dan paru, merubah kadar kolesterol, menghindari proses penuaan yang terlalu dini serta meningkatkan kualitas hidup.

Olahraga atau gerak badan akan menolong jantung, karena dengan berlahraga akan menguatkan otot-otot dan otot-otot ini dapat memompa darah balik ke jantung. Otot yang baik akan menolong peredaran darah yang baik, otot yang lemah atau otot yang tidak bergerak atau tidak berolahraga akan menghalangi peredaran darah yang baik sehingga memaksakan jantung bekerja lebih berat. Dengan melakukan olahraga yang teratur jantung seseorang akan menjadi lebih berdayaguna karena arteri yang mensuplai otot jantung dengan darah akan bertambah besar ukurannya, dan mengurangi risiko serangan jantung (Kuntaraf, 1993). Pendapat unu ditunjang oleh Setiabudi (1998) bahwa dengan berolahraga secara teratur akan membantu meningkatkan kekuatan, ketegaran dan daya tahan (endurance); melindungi tubuh terhadap penyakit-penyakit jantung, pembuluh darah dan paru, menghindari proses penuaan yang terlalu dini dan meningkatkan kualitas hidup.

Pendapat Cooper (1986) yang dikutip oleh Kuntaraf (1993) bahwa olahraga yang terbaik untuk kesehatan di antaranya adalah berenang, jalan cepat, jogging dan bersepeda, karena olahraga ini melibatkan seluruh otot utama dari tubuh. Untuk itu peneliti akan memprogramkan salah satu cabang olahraga renang dengan memberi latihan secara aerobuk dan anaerobik. Karena menurut Fox (1993), bahwa perubahan- 
perubahan akibat latihan dipengaruhi oleh frekwuensi, intensitas serta lamanya atau durasi latihan. Dikenal dua bentuk latihan berdasarkan predominannya, yaitu latihan aerobik dan latihan anaerobik. Latihan aerobik merupakan latihan yang berlangsung lama dengan intensitas yang rendah, dimana enersi predominannya berasal dari pembakaran karbohidrat dan lemak secara aerob, sedangkan latihan anaerobik berlangsung lebih singkat dengan intensitas yang tinggi dan enersi predominannya adalah ATP-PC serta glikolisis anaerob. Sehingga dalam penelitian ini akan membuktikan bahwa dengan berolahraga cukup efektif untuk menurunkan kadar kolesterol lemak darah, dimana dengan penurunan kadar kolesterol, Low Density Lipoproteun (LDL) dan menaikkan High Density Lipoprotein (HDL) bisa mencegah terjadinya penyakit jantung koroner. Dengan demikian peneliti dapat membandingkan antara latihan aerobik dan latihan anaerobik, mana yang lebih baik dalam mengurangi risiko penyakit jantung koroner.

Penelitian ini bertujuan untuk membuktikan perbedaan pegaruh latihan aerobik dan latihan anaerobik terhadap perubahan kadar kolesterol total, kolesterol HDL, kolesterol LDL serta rasio kolesterol HDL/LDL dalam plasma.

Lipid adalah sekumpulan senyawa didalam tubuh yang memiliki ciri-ciri serupa dengan malam, gemuk (grease), atau minyak. Karena bersifat hidrofobik, golongan senyawa ini dapat dipakai tubuh sebgai sarana yang bermanfaat untuk berbagai keperluan. Misalnya, suatu jenis lipid yang dikenal sebagai trigliserida berfungsi sebagai bahan bakar. Senyawa ini sangat efisien untuk dipakai sebagai simpanan bahan penghasil energi karena terkumpul dalam butir-butir kecil yang hampir bebas air (McGilvery, 1996).

Lipid dalam tubuh manusia, terutama didapatkan dari makanan yang kaya lemak, dan juga dapat melalui biosintesa Hidrat arang dan Protein (Ellefson, 1971). Kurang dari 95\% lipid dalam tubuh didapatkan dalam darah berkaitan dengan protein membentuk Lipoprotein (Guyton, 1991), Lipoprotein ini dapat larut dalam air dan bertindak sebagai alat transport lipid (yang tidak dapat larut dalam air), seperti asam lemak bebas, trigliserida, fosfolipida dan kolesterol. Fungsi lipid dalam tubuh adalah sebagai berikut (Ellefson, 1971) : (a) sumber energi tubuh, trigliserida dan asam lemak bebas merupakan cadangan energi tubuh dalam bentuk energi kimia; (b) bahan pembentuk membran sel dan membran organel; (c) isolator tubuh terhadap trauma maupun suhu. Pada metabolisme kolesterol dalam sel, di dalam plasma, kolesterol diangkut oleh lipoprotein menuju jaringan-jaringan tubuh untuk dipergunakan (Grundy, 1978). Lipoprotein yang terutama mengangkut kolesterol adalah LDL. Pada eksresi kolesterol, kolesterol di eksresikan terutama oleh hati, melalui sistem empedu, baik sebagai kolesterol maupun sebagai garam empedu. Hanya sebagian kecil saja padanya yang dikeluarkan bersama tinja, karena sebagian besar diresorbsi menuju hati kembali melalui siklus entero-hepatik (Martin, 1985).

Selanjutnya pada transpirtasi kolesterol, kolesterol dalam plasma diangkut dari hari kejaringan parifer oleh LDL, sedangkan kolesterol darijaringan parifer diangkutoleh LDL menuju hati untuk dieksresikan atau dikonversi menjadi garam empedu (Witzun, 1979). Pada transportasi lipid : lipoprotein dijelaskan bahwa lipid adalah bahan yang tidak dapat larut dalam air, maka untuk pengangkutannya dalam darah yang sebagian besar terdiri dari air, harus dalam bentuk lain yaitu lipoprotein. Lipoprotein adalah suatu pertikel dengan struktur tertentu yang disebut "pseudomikal" (Miller, 1979) dengan susunan sebagai berikut: (a) permukaan luar terdiri dari sejumlah protein yang disebut Apoprotein (Apolipoprotein $=$ Apo) dan lipid polar (kolesterol bebas dan fosfolipid); (b) bagian dalam atau inti terdiri dari lipid non polar yaitu trigliserida dan kolesterol ester.

Apoprotein memegang peranan penting dalam mempertahankan struktur partikel lipoprotein, selain itu Apoprotein juga berfungsi mengatur 2 macam enzim, yaitu Lecithin Cholesterol Acyl Transferase (LCAT), dan Lipoprotein Lipase (LPL). Kedua enzim ini memegang peranan penting dalam mempertahankanstrukturpartikel danmengatur kerja serta metabolisme lipoprotein yaitu sebagai alat pengangkut trigliserida dan kolesterol dalam plasma (Miller, 1979) yang disebut jalur pengangkut eksogen, sedangkan jalur pengangkut lipida indogen yaitu pengangkutan trigliserida dan kolesterol dari hati kejaringan perifer.Pada komposisi lipoprotein dalam plasma, komposisi lipoprotein terdiri dari bebrapa fraksi (Mayes, 1987; Sargowo, 1996) : (a) Kilomikron, (b) Very Low Density Lipoprotein (VLDL), (c) Intermediate Density Lipoprotein 
(IDL), (d) Low Density Lipoprotein (LDL), (e) High Density Lipoprotein (HDL).

Menurut Perkumpulan Endokrinolog Indonesia (Perkeni, 1995) yang dikutip oleh Askandar (1997) bahwa nilai Triad Lipid ideal pada manusia adalah sebagi berikut : (1) Kolesterol total < 20mg/dl; (2) Kolesterol HDL $>45$ - 55 mg/dl; (3) Kolesterol LDL <130 mg/ dl, (4) Trigliserida < $150 \mathrm{mg} / \mathrm{dl}$. Pendapat lain (Assmann, 1992) yang dikutip oleh Sargowo (1997) bahwa hubungan HDL dengan risiko penyakit jantung koroner adalah sebagai berikut temperatur hingga reaksi enzim berjalan baik. Pendapat Arnhein (1989) latihan adalah proses sistematis yang berulang-ulang, kerja yang meningkat dan juga sebagai proses belajar secara aklimatisasi. Pate (1984) mengartikan latihan sebagai pengikutsertaan secara sistematis dalam kerja dengan tujuan untuk meningkatkan kapasitas fungsional fisik dan penyesuaian diri terhadapp pembebanan sehungga mencapai kinerja olahraga yang tinggi. Latihan merupakan suatu proses mempersiapkan organisme olahragawan secara sistematis untuk mencapai prestasi maksimal dengan pemberian beban fisik

Hubungan HDL dengan Risiko PJK (Sargowo, 1996)

\begin{tabular}{cccc}
\hline HDL & Prognosis Baik & Risiko Normal & Risiko Tinggi \\
\hline Laki-laki & $>55 \mathrm{mg} \%$ & $35-55 \mathrm{mg} \%$ & $<35 \mathrm{mg} \%$ \\
Wanita & $>65 \mathrm{mg} \%$ & $45-65 \mathrm{mg} \%$ & $<45 \mathrm{mg} \%$ \\
\hline
\end{tabular}

Sedangkan pendapat dari Walter (1989) Lipid pada tikus adalah sebagai berikut : (1) kolesterol total 58 (44-46) mg/dl; (2) kolesterol HDL 34 (20-80) mg/dl; (3) triglyseridos 39 (39-128) $\mathrm{mg} / \mathrm{dl}$. Latihan fisik pada dasarnya adalah memberi tekanan pada tubuh manusia secara teratur, sistematik, berkesinambungan sedemikian rupa sehingga dapat meningkatkan kemampuan dalam melakukan kerja (Brooks, 1984). Dari latihan fisik yang dilakukan secara teratur, berkesinambungan yang dituangkan dalam program latihan akan meningkatkan kemampuan fisik secara nyata, namun tidak demikian halnya jika dilakukan secara tidak teratur (Astrand, 1986). Menurut Fox (1988) untuk melakukan latihan fisik yang benar harus diawali dengan peregangan otot rangka dan ligament diteruskan dengan pemanasan. Peregangan bertujuan agar unsur kelentukan tetap terjaga dan mencegah cidera otot. Menurut Brooks (1984) pemanasan bertujuan untuk mempersiapkan sirkulasi serta mengoptimalkan dan mental secara teratur, terarah, meningkat dan berulang-ulang (Soekarman, 1987).

Sistem TP-PC (Phosphagen System), ATP yang tersedia dakan otot sangat terbatas jumlahnya. Jika kita menghendaki kerja otot yang lama maka perlu pembentukan ATP kembali. Dalam pembentukan ATP kembali diperlukan senyawa yang dapat dengan cepat bereaksi dengan PC (Phospho-Creatine) yang juga tersimpan dalam otot. Oleh karena ATP dan PC mengandung senyawa phosphat $(\mathrm{P})$, maka sistem ini biasnya disebut Phosphagen System. Apabila PC memerlukan oksigen, jumlah simpanan PC di otot sangat terbatas, lebih kurang hanya 1517 milimole/ $\mathrm{kg}$ otot, namun PC merupakan senyawa kimia yang paling cepat bereaksi untuk membentuk ATP kembali (Fox, 1988). Dengan latihan yang tepat dan berat, maka jumla sistem ATP-PC tersebut dapat ditingkatkan.

Perkiraan persediaan enersi dalam tubuh melalui sistem ATP-PC (phosphagen) terlihat dalam tabel di bawah ini.

Tabel Perkiraan jumlah simpanan ATP-PC (Fox, 1988)

\begin{tabular}{lccc}
\hline & ATP & PC & Total Phosphagen (ATP + PC) \\
\hline 1. Muscular concentration & & & $19-23$ \\
a. mM/kg Muscle* & $4-6$ & $15-17$ & $570-690$ \\
b. mM total muscle mass & $120-180$ & $450-510$ & \\
2. Useful energy & & & $0.19-0.23$ \\
a. Kcl/kg musle & $0,04-0,06$ & $0.15-0.17$ & $5.7-6.9$ \\
b. Kcl total muscle mass & $1.2-1.8$ & $4.5-5.1$ & \\
\hline
\end{tabular}


$44 \mid$ Budijanto, Pengaruh Latihan Aerobik dan Anaerobik terhadap Profil Lipid ...

Sisrem phosphagen ini merupakan sumber enersi yang cepat sehingga dapat dipergunakan untuk keperluan olahraga yang memerlukan reaksi kimia panjang, tidak memerlukan oksigen, ATP-PC tersimpan dalam kontraktil otot (Fox,1988). Pada sistem gikolisis anaerobik penyediaan ATP masih dimungkinkan dengan pemecahan glikogen tanpa oksigen atau lazimnya dikenal sebagai glikolisis anaerobik (anaerobik glycolysis). Proses ini lebih kompleks dibandingkan dengan sistem phophagen.

Asam laktat dapat diubah menjadi glukosa lagi dalam hati. Glikolisis anaerobik ini seperti juga sistem phosphagen merupakan faktor yang penting dalam olahraga, karena dapat memberikan ATP dengan cepat. Untuk olahraga yang memakan waktu 1-3 menit enersi digunakan terutama dari glikosis ini. Asam laktat yang terbentuk dalam glikolisis anaerobik ini menurunkan $\mathrm{pH}$ atau meningkatkan kasaman dalam otot maupun darah. Perubahan $\mathrm{pH}$ ini akan menghambat reaksi kimia yang menyebabkan kelelahan (Fox, 1988).

Sistem aerobik, bila oksigen mencukupi untuk pembakaran, maka 1 mol glikogen dipecah secara sempurna menjadi $\mathrm{CO}_{2}$ dan $\mathrm{H}_{2}$ Omenghasilkan 39 ATP untuk reaksi tersebut diperlukan enzim yang kompleks dengan rangkaian reaksi yang panjang. Metabolisme aerobik ini meskipun terjadi di otot, tetapi letaknya agak jauh dari mekanisme kontraktil, karena itu pengaruhnya lebih lambat dan tidak dapat digunakan secara cepat. Reaksi aerobik ini terjadi dalam bentukan yang dinamakan mitochondria.

Sistem anaerobik dapat dibagi menjadi tiga mekanisme yaitu glikolisis anaerobik, siklus kreb's dan sistem transport elektron (Fox, 1988).

1. Rangkaian pertama perubahan meliputi pemecahan glikogen menjadi $\mathrm{CO}_{2}$ dan $\mathrm{H}_{2} \mathrm{O}$ disebut glikolisis. Dalam glikolisis ini terjadi reaksi sebagai berikut $\mathrm{L}$

Glukosa +2 ADP +2 Phosphat dengan enersi $\rightarrow 2$ asam piruvat $+2 \mathrm{ATP}+4 \mathrm{H}$

Glikosis anaerobik hanya sedikit perbedaan yaitu tersedianya oksigen yang cukup dan asam laktat yang tidak tertimbun. Jadi dengan adanya oksigen akan menghambat penumpukan asam laktat tetapi tidak menghalangi pembentukan ATP. Oksigen membantu mengubah asam laktat menhadi piruvat setelah ATP dibentuk kembali.

2. Siklus Kreb atau siklus asam trikarboksilat
Pemecahan glukosa selanjutnya ialah memecah2asam piruvatdengan pertolongan koenzim $\mathrm{A} \rightarrow$ asam piruvat + asetil koenzim $\mathrm{A}+2 \mathrm{CO}_{2}+4 \mathrm{H}$. Selanjutnya asetil koenzim A ini masuk kedalam dari Kreb atau Citric acid cycle atau tri carboxylio acid cycle. Asam lemak aktif ini akan amsuk ke dalam siklus oksidasi yang dinamakan beta oksidasi dan menjadi asetil koenzim A. Selanjutnya asetil koenzim A ini akan masuk kedalam siklus Kreb. Banyaknya ATP yang dihasilkan tergantung dari macam asam lemak yang dioksidasi

\section{METODE}

Penelitian ini merupakan penelitian eksperimental. Dalam penelitian ini menggunakan tiga prinsip penelitian eksperimental yaitu replikasi, randomisasi, dan kontrol atau perlakuan banding. Penelitian ini tergolong penelitian murni menggunakan rancangan "The Post Test OnlyControl Group Design"

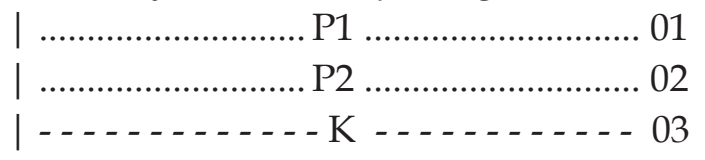

(Zainuddin, 1988)

\section{Keterangan}

$\mathrm{R}=$ Random $01=$ Post Test 1

P1 = Perlakuan $102=$ Post Test 2

$\mathrm{K}=$ Kelompok Kontrol

\section{Sampling dan Teknik Sampling}

Sampel pada penelitian ini digunakan hewan coba tikus putih jantan jenis rattus norvegicus wistar yang berasal dari UPT Hewan - Percobaan Universitas Gajahmada Yogyakarta sebanyak 30 ekor dengan pertimbangan : (a) tikus merupakan mamalia yang cukup dekat kekerabatannya dengan manusia, murah dan mudah pemeliharannya; (b) jumlah sampel telah memenuhi persyaratan; (c) hewan coba berkelamin jantan; (d) umur 88 - 94 hari $( \pm 3$ bulan) adalah usia dewasa dari tikus (Sesamto, 1988); (e) berat sekitar 200 - 210 gram

\section{Instrumen Penelitian}

Instrumen yang digunakan dalam penelitian ini yaitu berupa pengukuran kadar kolesterol - HDL, kolesterol - LDL, dan kolesterol total menggunakan metode CHOD - PAP, dimana 
pengambilan sampel darah dilakukan setelah latihan terakhir dan dipuasakan selama 8 jam (Sitepoe, 1997). Alat yang digunakan yaitu : (a) bak air sebagai kolam renang panjang 120 $\mathrm{cm}$, lebar $60 \mathrm{~cm}$, tinggi $80 \mathrm{~cm}$; (b) stop watch (merek braintek); (c) timbangan (merek philip harris s); (d) lempengan logam sebagai beban; (e) ether anaestheticum; (f) tabung gelas; (g) kapas; (h) gunting; (i) disposible syringe $3 \mathrm{ml}$; (j) alat pemusing (sentrifuge) merek Herauseus Sepatech; (k) botol kecil $5 \mathrm{ml}$.

Metode latihan yang dilakukan yaitu latihan yang berlangsung selama 8 minggu. Hal ini berdasarkan pertimbangan sebagai berikut; (a) perubahan kolesterol - HDL mulai nampak setelah latihan 6 minggu (Schriewer, 1984); (b) frekwensi 3 kali seminggu merupakan frekwensi yang sesuai bagi pemula, disamping cukup memberikan kesempatan kepada tubuh untuk mengalami eroode penelitian; (c) lama latihan 13 menit baik untuk kelompok aerobik maupuk untuk kelompok anaerobik

\section{HASIL DAN PEMBAHASAN}

Penelitian ini bertujuan untuk mengetahui pengaruhlatihan aerobik dan anaerobik terhadap profil lipid. Penelitian ini menggunakan metode eksperimental laboratoris dengan pertimbangan sebagai berikut: (a) jenis eksperimental laboratoris cukup memadai untuk memenuhi tujuan dalam penelitian ini; (b) sejumlah variabel dapat dikuasai, dikendalikan serta dimanipulasi (Praktiknya, 1986); (c) validitas internal ditingkatkan dengan pemberian perlakuan banding dan replikasi (Zainudin, 1988); (d) secara teknis lebih sederhana, ekonomis (Praktiknya, 1986); (e) masing - masing kelompok mendapat kandang, diet, dan lingkungan yang sama.

Latihan aerobik dan latihan anaerobik yang diprogramkan melalui renang merupakan salah satu bentuk yang dipakai perlakuan pada hewan coba, latihan ini dilakukan secara teratur dan berulang-ulang sesuai dengan program latihan. Kelompok kontrol dibandingkan dengan kelompok aerobik.

1. Perubahan pada kholesterol total

Latihan aerobik dapat menurunkan kadar kolesterol total yang sesuai dengan hasil penelitian ini, yaitu terdapat penurunan yang bermakna pada kelompok aerobik $(\mathrm{P}=0,000)$ sesuai dengan pendapat Marrugat (1996) bahwa dengan meningkatnya konsentrasi kolesterol HDL maka akan menurunkan kadar kolesterol total pada seseorang yang melakukan latihan secara teratur. Sedangkan menurut Kuntaraf (1992) dengan latihan aerobik akan menurunkan kadar kolesterol total.

2. Perubahan pada kolesterol HDL

Latihan aerobik dapat meningkatkan kadar kolesterol - HDL sehingga menunjukkan perbedaan yang bermakna $(P=0,000)$. Hal ini dapat ditarik alasan sebagai berikut: (a) latihan renang merupakan salah satu bentuk latihan ketahanan yang menyebabkan meningkatnya aktivitas lipoprotein lipase (LPL) pada ototjaringan danjaringan edipose sehingga terjadi peningkatan pemecahan lipoprotein yang kaya TG, dengan akibat TG plasma maenurun, bersamaan dengan kolesterol HDL meningkat (Schriewer, 1984); (b) peningkatan aktivitas enzim Lecithin Cholesterol Acyl-Transfer (LCAT) (Simko, 1979) yang mengatakusasu reaksi perubahan kholesterol menjadi ester kholesterol. Enzim ini bertanggung jawab untuk mentransport kholesterol dari sel parifer ke liver; (c) penurunan kadar insulin plasma mengakibatkan penurunan Trigliseride plasma sehingga kholesterol HDL meningkat; (d) terjadinya peningkatan sensititas jaringan edipose yang terpisah, terhadap aksi lipolitik dari epineprin (Wardzala, 1962). Dari keempat alasan inilah yang menyebabkan terjadinya peningkatan kholesterol - HDL akibat latihan aerobik.

3. Perubahan pada kholesterol - LDL

Sesuai dengan penelitian terjadi perbedaan penurunan yang bermakna $(\mathrm{P}=0,000)$. Rangsangan hormon tiroid dapat meningkatkan pembentukan reseprot LDL di hati. Hati merupakan organ yang berperan dalam pembersihan LDL dari plasma, karena ukurannya yang cukup besar dan mempunyai konsentrasi reseptor :D: yang tinggi (Brown, 1984). Olahraga yang dilakkan dengan waktu yang lama, dengan intensitas cukup tinggi akan meningkatkan aktivitas hormon tiroid dan latihan akan meningkatkan metabolisme hormon tiroid (Fox, 1993). Peningkatan enzim LCAT dapat mengakibatkan terjadinya penurunan VLDL dan LDL, dna penurunan kadar insulin plasma akan mengakibatkan peningkatan sintesa reseptor LDL menurun 
46 | Budijanto, Pengaruh Latihan Aerobik dan Anaerobik terhadap Profil Lipid ...

(Simko, 1979). Kemungkinan hal-hal inilah yang mengakibatkan kholesterol - LDL mengalami penurunan akibat latihan aerobik.

Kelompok kontrol dibandingkan dengan kelompok anaerobik.

1. Terhadap perubahan kolesterol total

Hasil penelitian menunjukkan adanya penurunan yang bermakna $(\mathrm{P}=0,002)$. Sesuai dengan pendapat Ohkuwa (1993) bahwa dari 10 laki-laki yang diberikan perlakuan berenang $100 \mathrm{M}$ secara anaerobik nampak ada peningkatan secara nyata pada kolesterol HDL, Trigleserida akan tetapi pada kolesterol total tidak ada peningkatan secara nyata sehingga disarankan latihan anaerobik dapat dijadikan saru alasan untuk meningkatkan kadar kolesterol HDL.

2. Terhadap perubahan kolesterol HDL

Hasil penelitian menungkukkan adanya perbedaan yang meningkat dan bermakna $(\mathrm{P}=0,015)$. Pada olahraga anaerobik terjadi peningkatan asam laktat darah, yang mana merupakan inhibitor fisiologis terhadap mobilisasi FFA (Astrand, 1986) mobilisasi Ffa ini adalah akibat rangsangan saraf simpatis pada jaringan adiposa yang terpisah dapat dinetralisir oleh pemberian asam laktat dalam konsentrasi fisiologis. Tetapi setelah berhenti dari suatu aktivitas anaerobik, terjadi peningkatan kadar FFA plasma yang berlangsung selama beberapa jam, atau biasanya sampai waktu makan berikutnya. Hal ini akibat pengaruh dari hormon pertumbuhan (Astran, 1986).

3. Terhadap perubahan kolesterol LDL

Hasil penelitian menunkukkan adanya suatu perbedaan yang lebih rendah dan bermakna $(\mathrm{P}=0,001)$. Penurunan LDL oada latihan anaerobik adalah akibat hormon tiroid, disamping adanya pengaruh insulin yang akan merangsang pengikatan LDL dan proses internalisasi LDL melalui aktivitas reseptor (Shepherd, 1984)

Kelompok aerobik dibandingkan dengan kelompok anaerobik

1. Terhadap kolesterol Totoal

Hasil penelitian menunjukkan perbedaan yang bermakna $(P=0,010)$. Dengan menurunnya kadar kolesterol total pada latihan aerobik dibandingkan dengan latihan anaerobik dapat disimpulkan bahwa pada latihan aerobik kemungkinan terjadinya aterosklerosis sangat kecil. Sedangkan penurunan kolesterol total pada latihan anaerobik mekanismenya belum diketahui.

2. Terhadap kolesterol HDL

Hasil penelitian menunjukkan perbedaan yang bermakna $(\mathrm{P}=0,014)$. Hal ini disebabkan periode oemulihan aktivitas anaerobik berjalan secara aerobik. Pendapat Astrand (1986), pada saat itu kadar FFA darah terlihat sangat meningkat selama beberapa jam, yang terjadi karena pengaruh hormon pertumbuhan. Meningkatnyna kadar FFA darah menunjukkan adanya peningkatan lipolisis sesudah olahraga anaerobik. Tetapi jika dibandingkan dengan aerobik lebih meningkatkan HDL dari pada anaerobik.

3. Terhadap kolesterol LDL

Hasil penelitian menunjukkan perbedaan yang bermakna antara kelompok aerobik dan anaerobik $(\mathrm{P}=0,006)$. Hal ini disebabkan menurunnya LDL pada latihan anaerobik juga sesuai dengan latihan aerobik. Menurut Dangsina (1995) bahwa menurunnya LDL kolesterol berkaitan dengan naiknya kadar HDL kolesterol, karena meningkatnya HDL yang tinggi berkaitan dengan peningkatan keaktifan kapiler sehingga aktivitas enzim lipoprotein lipase meningkat.

\section{KESIMPULAN DAN SARAN}

Berdasarkan hasil penelitian pengaruh latihan aerobik dan anaerobik terhadap profil lipid pada tikus rattus norvegicus wistar, dapat disimpulkan bahwa, latihan aerobik dapat menurunkan kadar kolesterol total, meningkatkan kadar kolesterol HDL, menurunkan kolesterol LDL dan meningkatkan rasio HDL/LDL bila dibandingkan dengan kelompok kontrol. Selanjutnya pada latihan anaerobik dapat menurunkan kadar kolesterol total, meningkatkan kadar kolesterol HDL, menurunkan kadar kolesterol LDL dan meningkatkan rasio HDL/LDL bila dibandingkan dengan kelompok kontrol. Pada latihan aerobik lebih baik jika dibandingkan dengan latihan anaerobik dalam menurunkan kadar kolesterol total dan kolesterol LDL, dalam meningkatkan kadar kolesterol HDL dan rasio HDL/LDL 
Berdasarkan hasil penelitian yang telah dilakukan, dapat diterapkan pada manusia untuk melakukan olahraga secara teratur dan benar. Untuk menghindari terkenanya penyakit jantung koroner dengan merubah profil lipid, dapat dilakukan baik latihan aerobik maupun latihan anaerobik. Tetapi dengan bertambahnya usia (bagi orang dewasa) lebih disarankan latihan aerobik.

\section{DAFTAR RUJUKAN}

Arnheim D.D. 1989. Modern Prinsiples of Atletic Training, Santa Clara. CV Mosby Company

Astrand P.O. and Rodhal K. 1986. Text Book of Work Physiology, 2nd ed. New York: Lea \& McGraw-Hill Book Company

Brooks G.A and Fahay T.D,. 1988. Excercise of Physiology Human Bionergyties and its Aplication. New York. John Withley and Soon

Brown M.S and Goldberg T.J, and Geinsberg H.N. 1984. Tretment of Commmon Lipoprotein Disorders. Cardiovascular Trend.

Ellefson R.D.1971. Lipid Metabolism and Diagnostic Aplication. BBM. New York

Fox E.1, Bower R.W and Foss M.L. 1988. The Physiological Basis of Physical Education and Athetics. Philadelphia. Saunders colege publishing

Fox E1, Bowers R.W and Foss M.L. 1993. The Physiologycal Basis for Exercise and Sport. Dubuqu Lowa; Brown and Benchmark publishers, Madison, Wiscon in

Guyton A.C. 1991. Textbook of Medical Physiology. Philadelphia : WB Saunders Company

Grundy S.M. 1978. Cholesterol Metabolism in Man. The Western Journal of medicine
Kuntaraf, J. 1993. Olahraga Sumber Kesehatan. CV Adven Indonesia Edisi 4

Martin D.W, Mayes, Rodwell VW and Granner DK. 1985. Harper's Review of Biochemetry, 20th in Tokyo. Maruzen Co. LTD

Marrugat J., Elosoa R., Cobas M.I., Molina L and Rubies-Prat J. 1996. Amoun and Intensity of Physical Fitness amd Serum Lipids in Men. The Marathin Invertigators. Am. Journal Epidemiol

Mayes. 1987. Metabolisme Lipid, Asam Lemak, Peranan Jaringan. CV EGC. Jakarta

McGilvery R.W. 1996. Biokimia Suatu Pendekatan Fungsional ed. 3. Universitas Airlangga

Miller N.E. 1979. Plasma Lipoprotein, Lipid Transport adn Atherosclerosis. Recent developments, Journal Clinical Phatology

Ohkuwa T and Itoh H. 1993. High Density Lipoprotein Cholesterol Following Anaerobic Swimming in Trained Swimers. J. Sport Med Phys Fitness

Pate $\mathrm{R}$ and McClenaghan. 1984. Scientific Faundation of Coaching. Philadelpia. Saunders College Publishing

Simko V and Kelly R.E. 1979. Effect of Chronic Intermitten Exercise on Biliary Lipids, Plasma Licithin Cholesterol Acyl. Cal nutrition

Soekarman R. 1987. Dasar Olahraga Untuk Pembina dan Pelatih dan Atlit. Jakarta : Inti Indayu Press

Sitepoe M. '997. Penyakit Jantung dan Usaha Pencegahan. Gramedia Jakarta

Wardzala L.J. Et. Al. 1982. Physical Training of Lean and Genetically ObeseZucker Rats. Effect On Fat Cell Metabolism. Am. J. Physiol 
48 | Budijanto, Pengaruh Latihan Aerobik dan Anaerobik terhadap Profil Lipid ... 